\title{
Bacillus amyloliquefaciens (IAE635) and their metabolites could purify pollutants, Vibrio spp. and coliform bacteria in coastal aquaculture wastewater
}

\author{
Yalu Shao ${ }^{1,2}$, Hua Zhong ${ }^{1 *}$, Liangkai Wang ${ }^{3}$, Mohammed M. A. Elbashier ${ }^{3}$ \\ (1. State Key Laboratory of Water Resources and Hydropower Engineering Science, Wuhan University, Wuhan 430072, China; \\ 2. School of Agriculture and Food, The University of Melbourne, Victoria 3010, Australia; \\ 3. College of Agricultural Sciences and Engineering, Hohai University, Nanjing 210098, China)
}

\begin{abstract}
High-density aquaculture often causes the emission of polluted water to the marine environment in the coastal areas of China. To solve the aquaculture-related water quality problems, it is appropriate to adapt eco-friendly methods, such as using microbes and their metabolic products to purify polluted water. In this study, the purifying effects of Bacillus amyloliquefaciens (IAE635) metabolites (poly- $\gamma$-glutamic acid; PP) and IAE635 combined with their metabolites (MP) on turbidity, $\mathrm{COD}, \mathrm{NO}_{3}{ }^{-}-\mathrm{N}, \mathrm{NH}_{4}{ }^{+}-\mathrm{N}$, Vibrio spp. and coliform bacteria in coastal aquaculture wastewater were conducted in the lab and in situ ponds. The results showed that the removal of turbidity, $\mathrm{COD}, \mathrm{NH}_{4}{ }^{+}-\mathrm{N}$ and $\mathrm{NO}_{3}{ }^{-}-\mathrm{N}$ with $\mathrm{PP}$ and MP was more significant $(p<0.05)$. Compared to Control treatment $(\mathrm{Co})$, the turbidity, $\mathrm{COD}, \mathrm{NH}_{4}{ }^{+}-\mathrm{N}$ and $\mathrm{NO}_{3}{ }^{-}-\mathrm{N}$ concentrations at $24^{\text {th }}$ hour were evidently reduced by $86.6 \%, 87.5 \%, 83.3 \%$ and $58.0 \%$ for PP, $87.9 \%, 93.5 \%, 86.5 \%$ and $78.0 \%$ for MP, respectively. The populations of water pathogens under PP and MP were also significantly $(p<0.05)$ removed compared with those of Co; at $24^{\text {th }}$ hour, the Vibrio spp. and coliform bacteria were decreased by $68.7 \%$ and $66.3 \%$ for PP, $75.0 \%$ and $67.1 \%$ for MP, respectively. The water purifying effect of MP was slightly better than that of PP. In situ pond purification test demonstrated that MP significantly lowered the concentrations of turbidity, $\mathrm{COD}, \mathrm{NH}_{4}{ }^{+}-\mathrm{N}, \mathrm{NO}_{3}{ }^{-} \mathrm{N}$ and $\mathrm{NO}_{2}^{-}-\mathrm{N}$, which was more effective than EM. A significantly higher $(p<0.05) \gamma$-PGA concentration and the total bacterial population for MP compared to PP indicated that MP purifies the coastal aquaculture wastewater by both flocculation and microbial decomposition. The application of MP will benefit the aquaculture industry by providing a novel method for the removal of chemical pollutants and pathogens.
\end{abstract}

Keywords: coastal aquaculture, Bacillus amyloliquefaciens and their metabolites (MP), bio-flocculants, chemical pollutants, Vibrio spp., coliform bacteria, wastewater purification

DOI: $10.25165 /$ j.ijabe.20211402.6082

Citation: Shao Y L, Zhong H, Wang L K, Elbashier M M A. Bacillus amyloliquefaciens (IAE635) and their metabolites could purify pollutants, Vibrio spp. and coliform bacteria in coastal aquaculture wastewater. Int J Agric \& Biol Eng, 2021; 14(2): 205-210.

\section{Introduction}

With the recent rapid development of aquaculture in China, high-density and intensive breeding have become the most widely used approaches. For the intensive aquaculture, there are often residual feed, faeces and pathogens in the water ${ }^{[1-3]}$. Typically, it is characterized by increased nitrogen forms $\left(\mathrm{NH}_{4}{ }^{+}-\mathrm{N}, \mathrm{NO}_{2}{ }^{-}-\mathrm{N}\right.$ and $\mathrm{NO}_{3}^{-}-\mathrm{N}$ ), phosphates, suspended solids, BOD and COD as well as high populations of the opportunistic pathogen ${ }^{[2,4,5]}$. If the aquaculture water is untreated, it will result in the emission of nutrient-rich effluents that causes algae blooms, degradation of benthic communities, oxygen depletion and destruction of water

\section{Received date: 2020-08-14 Accepted date: 2021-01-31}

Biographies: Yalu Shao, $\mathrm{PhD}$ candidate, research interests: remediation of contaminated soil and water environment, Email: shaoyalu@hotmail.com; Liangkai Wang, $\mathrm{PhD}$ candidate, research interests: agricultural biology and environment engineering, Email: wangliangkai93@163.com; Mohammed M. A. Elbashier, PhD, research interests: agricultural water and soil engineering, Email: mohammedltr@hotmail.com.

*Corresponding author: Hua Zhong, Professor, research interests: remediation of contaminated soil and water environment. State Key Laboratory of Water Resources and Hydropower Engineering Science, Wuhan University, Wuhan 430072, China. Tel: +86-27-68772215, Email: zhonghua21cn@126.com. quality $^{[4,6]}$. Current practices for treating aquaculture wastewater include exchange with freshwater, sequencing batch reactors, wetland and filter systems ${ }^{[4,7,8]}$. However, the high cost of these methods decreases their widespread application.

In situ purification of wastewater in the aquaculture pond can decrease the quantity of water that should be exchanged, and therefore, it is a lower cost method with less discharge. Flocculation or coagulation is an effective method to quickly purify wastewater by using materials such as chitosan, polyacrylamide, or polymeric aluminium sulfate $e^{[9-11]}$. While these chemical flocculants have been shown to remove various toxins, most of them are not suitable for application in aquaculture with regard to food safety. Bioflocculants have been investigated for the removal of COD, nitrogen and organic pollutants of wastewater from brewing, meat processing, soy sauce brewing, and pharmaceutical and dairy production ${ }^{[12-14]}$. Additionally, for river water with low turbidity, a Serratia ficaria bioflocculant achieved removal efficiencies of $87.1 \%$ for COD and $84.2 \%$ for turbidity, which was better than that obtained with similar chemical synthetic flocculants ${ }^{[13,15,16]}$. Bioflocculants have been demonstrated to be effective in flocculating aquatic microbes as well. For example, the extracellular biopolymer produced by Paenibacillus polymyxa was shown to have a flocculating activity of up to $95 \%$ for algae ${ }^{[17]}$. 
Moreover, the bioflocculant exuded by Klebsiella pneumoniae was used to remove Acanthamoeba cysts, an aquatic pathogenic amoeba, with a maximum removal efficiency of $84 \%^{[18]}$. A flocculant from another Klebsiella spp., Klebsiella terrigena, has been shown to remove Cryptosporidium oocysts from tap water with a removal efficiency of $62.3 \%{ }^{[18]}$.

Regarding the environmental problems caused by high-density aquaculture industry, it may be an appropriate approach for the application of microbes and their metabolic products to purify polluted waters. The study presented here examined the efficacy of MP as bioflocculant for treating the wastewater from an intensive shrimp aquaculture pond. As a biological purification method, the addition of MP would result in a reduction of COD, inorganic nitrogen and aquatic pathogens, which could assist for the healthy development of the aquaculture in coastal regions. Furthermore, the process described here, once scaled up, could provide an alternative method to high cost or chemically prohibitive aquaculture wastewater purification, which is of considerable significance to guarantee the sustainable development of the aquaculture industry in China.

\section{Materials and methods}

\subsection{Microbes and medium}

Bacillus amyloliquefaciens IAE635, which are capable of poly- $\gamma$-glutamic acid $(\gamma$-PGA) production, were isolated from coastal alkali-saline soil and obtained from the China Center for Type Culture Collection (accession number CCTCC 2013086). The $\gamma$-PGA culture medium of IAE635 was prepared using $35.3 \mathrm{~g}$ glutamate, $16.7 \mathrm{~g}$ citrate, $92.6 \mathrm{~g}$ glycerin, $1.2 \mathrm{~g}$ yeast extract, $1 \mathrm{~g}$ $\mathrm{KH}_{2} \mathrm{PO}_{4}$, and $0.5 \mathrm{~g} \mathrm{MgSO}_{4}$. The medium was amended with $100 \mathrm{~mL}$ distilled water, with a $\mathrm{pH}$ ranging from 6.0-6.3. Then, the prepared media were autoclaved for $20 \mathrm{~min}$ at $121^{\circ} \mathrm{C}$. The concentration of $\gamma$-PGA produced by IAE635 fermentation was measured and determined to be $23.8 \mathrm{~g} / \mathrm{L}^{[19]}$.

The above fermented mixture (IAE635 and their metabolite $\gamma$-PGA) was reacted with the solution consisting of $2.6 \mathrm{~g} / \mathrm{L}$ $\mathrm{Ca}(\mathrm{OH})_{2}, 5.1 \mathrm{~g} / \mathrm{L} \mathrm{CaCO}_{3}$ and $13.8 \mathrm{~g} / \mathrm{L} \mathrm{CaCl}_{2}$ by shaking at $150 \mathrm{r} / \mathrm{min}$ at $15^{\circ} \mathrm{C}$ for $10 \mathrm{~min}$. This mixture solution was stored at $4^{\circ} \mathrm{C}$ and designated as IAE635 and their metabolite $\gamma$-PGA (MP).

Consistent with the concentration of $\gamma$-PGA produced by IAE635 fermentation, pure $\gamma$-PGA was dissolved in sterile tap water at a concentration of $23.8 \mathrm{~g} / \mathrm{L}$. This solution was also kept at $4^{\circ} \mathrm{C}$ as the same as MP. The solution was designated as the pure $\gamma$-PGA solution (PP).

\subsection{Experimental design}

Water samples were collected from an intensive shrimp (Litopenaeus vannamei) aquaculture pond in Dongtai City, Jiangsu Province, China. The aquaculture water collection buckets were stainless steel cylinders and the collected water from different depths of aquaculture pond was filled by a bottom-sealed polymethyl methacrylate (PMMA) tube with a diameter of $10 \mathrm{~cm}$ and height of $120 \mathrm{~cm}$. Table 1 indicates the initial properties of the aquaculture water before the purification experiments.

Three treatments were designed as presented in Table 2.

For each treatment, a $5 \mathrm{~L}$ aquaculture water sample was placed in the PMMA tube. Each treatment was replicated 3 times. After PP or MP addition, it was stirred with a $20 \mathrm{~cm}$ glass stick at $70 \mathrm{r} / \mathrm{min}$ for $10 \mathrm{~s}$ and then kept stationary for $24 \mathrm{~h}$. Experiments were conducted in the greenhouse at temperatures of $29^{\circ} \mathrm{C}-40^{\circ} \mathrm{C}$ (day) and $15^{\circ} \mathrm{C}-30^{\circ} \mathrm{C}$ (night) with a natural photoperiod. To evaluate the purification effects of the aquaculture wastewater, samples were collected from the PMMA tube at a depth of $60 \mathrm{~cm}$ at $0.5^{\text {th }} \mathrm{h}, 1^{\text {st }} \mathrm{h}, 12^{\text {th }} \mathrm{h}$ and $24^{\text {th }} \mathrm{h}$ for each treatment. Some related water quality indicators (turbidity, $\mathrm{COD}, \mathrm{NH}_{4}{ }^{+}-\mathrm{N}, \mathrm{NO}_{3}{ }^{-} \mathrm{N}$ and populations of Vibrio spp., faecal coliform and total bacteria) were selected to determine for each treatment at four sampling time points.

Table 1 Main water quality parameters $($ Mean \pm SD) of the study aquaculture pond

\begin{tabular}{|c|c|c|}
\hline \multicolumn{2}{|r|}{ Water qualities } & Concentrations \\
\hline \multicolumn{2}{|c|}{$\mathrm{NH}_{4}{ }^{+}-\mathrm{N} / \mathrm{mg} \cdot \mathrm{L}^{-1}$} & $1.02 \pm 0.14$ \\
\hline \multicolumn{2}{|c|}{$\mathrm{COD} / \mathrm{mg} \cdot \mathrm{L}^{-1}$} & $25.50 \pm 2.04$ \\
\hline \multicolumn{2}{|c|}{ Turbidity/NTU } & $56.11 \pm 3.29$ \\
\hline \multicolumn{2}{|c|}{$\mathrm{DO} / \mathrm{mg} \cdot \mathrm{L}^{-1}$} & $7.11 \pm 0.54$ \\
\hline \multicolumn{2}{|c|}{$\mathrm{NO}_{3}{ }^{-}-\mathrm{N} / \mathrm{mg} \cdot \mathrm{L}^{-1}$} & $25.54 \pm 1.26$ \\
\hline \multicolumn{2}{|c|}{ Vibrio spp. $/ 10^{2} \mathrm{cfu} \cdot \mathrm{mL}^{-1}$} & $13.2 \pm 0.85$ \\
\hline \multicolumn{2}{|c|}{ Faecal coliform $/ 10^{2} \mathrm{cfu} \cdot \mathrm{mL}^{-1}$} & $7.20 \pm 0.63$ \\
\hline \multicolumn{2}{|c|}{ Total bacteria $(60 \mathrm{~cm}) / 10^{5} \mathrm{cfu} \cdot \mathrm{mL}^{-1}$} & $9.20 \pm 0.95$ \\
\hline \multicolumn{2}{|c|}{ Total bacteria $(119 \mathrm{~cm}) / 10^{6} \mathrm{cfu} \cdot \mathrm{mL}^{-1}$} & $1.60 \pm 0.11$ \\
\hline \multicolumn{3}{|c|}{ Table 2 Experimental treatments } \\
\hline \multicolumn{2}{|l|}{ Treatment } & Description \\
\hline Co & \multicolumn{2}{|c|}{ Without adding PP or MP in the aquaculture water } \\
\hline PP & \multicolumn{2}{|c|}{$\begin{array}{l}\text { Adding PP to a final concentration of } 2 \mathrm{~mL} / \mathrm{L} \text { in the aquaculture } \\
\text { water }\end{array}$} \\
\hline MP & \multicolumn{2}{|c|}{$\begin{array}{l}\text { Adding MP to a final concentration of } 2 \mathrm{~mL} / \mathrm{L} \text { in the aquaculture } \\
\text { water }\end{array}$} \\
\hline
\end{tabular}

In situ purification of intensive shrimp pond water was also conducted in Dongtai City by choosing an aquaculture farm located in coastal area, Jiangsu Province by which to compare the purifying effects of MP with EM, a commercial aquaculture water purification agent. Three treatments were set up as follows: (1) Control, without using any water purification agent in the aquaculture pond; (2) EM and (3) MP, $4000 \mathrm{~mL}$ of EM or MP was used per $667 \mathrm{~m}^{2}$ of each aquaculture pond, EM or MP was mixed with aquaculture water at a volume ratio of 1:1000 and uniformly applied to the breeding pond via an electric spray. Water samples at the depth of $60 \mathrm{~cm}$ had been taken in three different places on the seventh day of each treatment. Numerical values of the water quality indicators for turbidity, $\mathrm{COD}, \mathrm{NH}_{4}^{+}-\mathrm{N}, \mathrm{NO}_{2}^{-}-\mathrm{N}$ and $\mathrm{NO}_{3}^{-}-\mathrm{N}$ were determined and compared.

\subsection{Water chemical properties determination}

The turbidity of the water was measured using a WGZ turbimeter (Shanghai Licheng Technology Co., Ltd., China). The dissolved oxygen (DO) was measured using a dissolved oxygen analyser JPB-607 (Shanghai INESA Scientific Instrument Co., Ltd., China). The COD, $\mathrm{NO}_{3}^{-}-\mathrm{N}, \mathrm{NH}_{4}{ }^{+}-\mathrm{N}$ and $\mathrm{NO}_{2}^{-}-\mathrm{N}$ levels were assayed using the method described by Fan et al. ${ }^{[7]}$ and Travaini-Lima et $\mathrm{al}^{[8]}$. The $\gamma$-PGA concentration was measured using the method described by Ghosh et $\mathrm{al}^{[20]}$.

\subsection{Determinations of total bacteria, faecal coliform bacteria and Vibrio spp. in water}

All bacterial populations are represented as colony forming units $(\mathrm{cfu} / \mathrm{mL})$. Water samples were collected from the pipes at depths of 60 and $119 \mathrm{~cm}$. Total bacterial counts were examined according to the method described by Chen et $\mathrm{al}^{[19]}$. Briefly, coated ten-fold serial dilutions of the water sample were plated on beef peptone agar. The plates were incubated at $37^{\circ} \mathrm{C}$ for $24 \mathrm{~h}$, and the total colonies were counted. Faecal coliform bacteria were enumerated by filtering $100 \mathrm{~mL}$ of the water samples through 
a $0.45 \mu \mathrm{m}$ membrane followed by inoculation on M-FC agar. These samples were incubated at $(44.5 \pm 0.2)^{\circ} \mathrm{C}$ for $24 \mathrm{~h}$ prior to evaluation. Blue colonies on the M-FC agar were considered positive for faecal coliform $^{[21]}$. Vibrio spp. were determined according to Kriem et $\mathrm{al}^{[22]}$. The spread-plate method was utilized with thiosulfate-citrate bile salts (TCBS) agar. The plates were incubated for $3 \mathrm{~d}$ at $20^{\circ} \mathrm{C}$, and yellow-, green- or blue green-coloured colonies were considered positive for Vibrio spp.

\subsection{Statistical analysis}

The experimental results were averaged over three replicates. The data were analyzed by using SPSS 18.0 software. Analysis of variance (ANOVA) was used in these tests, and the separation of means of the treatments was performed with Tukey's test $(p<0.05)$ according to the methods of Ruxton et al ${ }^{[23]}$. The GraphPad Prism 6 software package was used to generate the graphs to present the experimental results.

\section{Results}

\subsection{Changes in water quality under different treatments}

Figure 1 shows that turbidity, $\mathrm{COD}, \mathrm{NH}_{4}{ }^{+}-\mathrm{N}$ and $\mathrm{NO}_{3}{ }^{-}-\mathrm{N}$ have a similar change trend with the reaction time for $\mathrm{Co}$, PP and MP treatments. Generally, there was no evident change for above water quality parameters during $1^{\text {st }} \mathrm{h}$, but significant $(p<0.05)$ differences were observed at both $12^{\text {th }}$ and $24^{\text {th }} \mathrm{h}$. At $24^{\text {th }} \mathrm{h}$, compared to the $\mathrm{Co}$, turbidity, $\mathrm{COD}, \mathrm{NH}_{4}{ }^{-}-\mathrm{N}$ and $\mathrm{NO}_{3}{ }^{-} \mathrm{N}$ were decreased by $86.6 \%, 87.5 \%, 83.3 \%$ and $58.0 \%$ in PP, while they were $87.9 \%, 93.5 \%, 86.5 \%$ and $78.0 \%$, respectively in MP. The DO under all treatments showed no evident difference at $1^{\text {st }} \mathrm{h}$ (Figure 1e); however, a significant $(p<0.05)$ decrease in DO was observed at $12^{\text {th }}$ and $24^{\text {th }} \mathrm{h}$. Compared to the PP and MP, the DO in the Co was lowered by $41.7 \%$ and $37.8 \%$ at $12^{\text {th }} \mathrm{h}$, while it was reduced by $63.3 \%$ and $56.0 \%$, respectively at $24^{\text {th }} \mathrm{h}$.

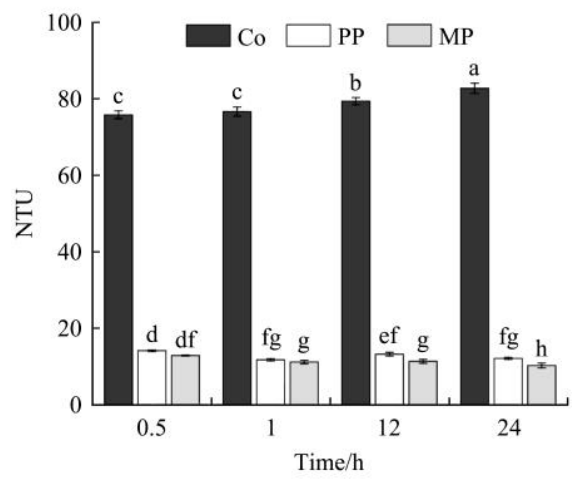

a. Turbidity

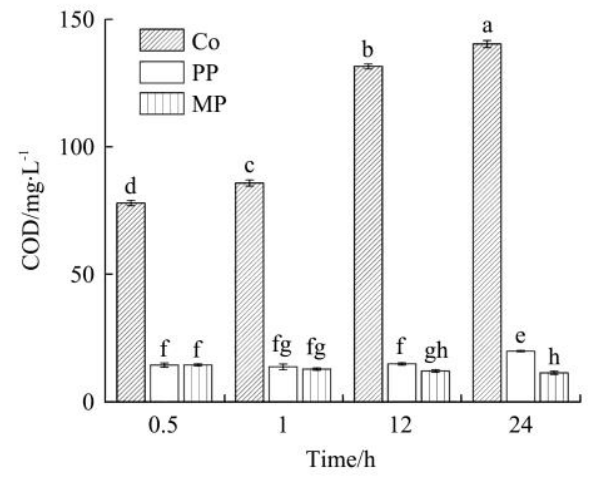

b. COD

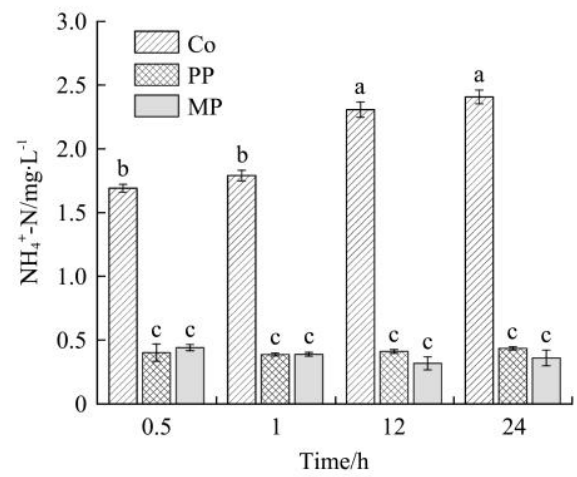

c. $\mathrm{NH}_{4}^{+}-\mathrm{N}$

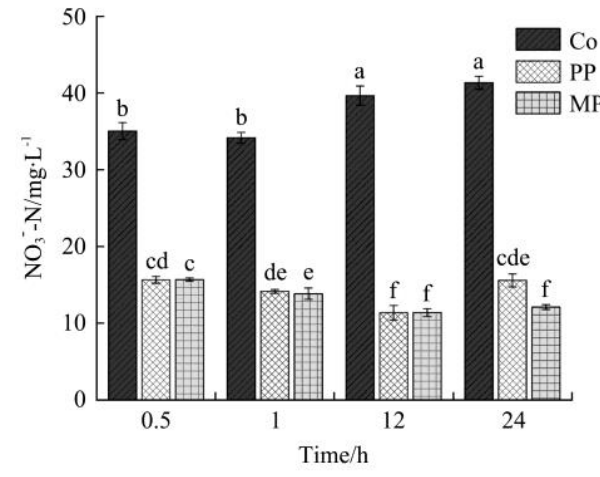

d. $\mathrm{NO}_{3}{ }^{-}-\mathrm{N}$

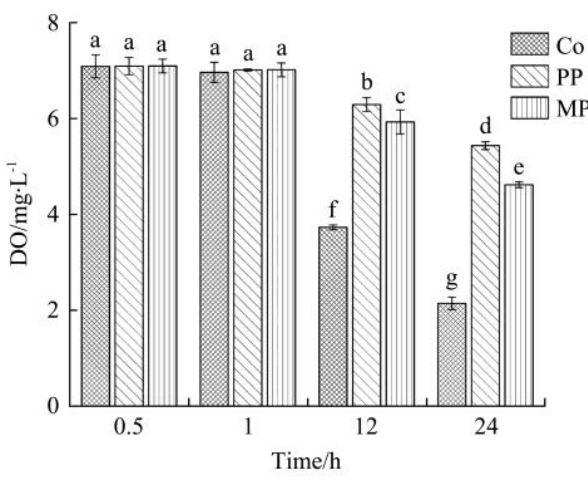

e. DO

Note: Means followed by the different lowercase letters are significantly difference at the 0.05 level $(p<0.05)$.

Figure 1 Effect of MP and PP on the (a) turbidity, (b) $\mathrm{COD}$, (c) $\mathrm{NH}_{4}{ }^{+}-\mathrm{N}$, (d) $\mathrm{NO}_{3}{ }^{-}-\mathrm{N}$, and (e) DO in aquaculture wastewater (60 cm samples)

\subsection{Effects of MP and PP on Vibrio spp., faecal coliform and} total bacteria ( $60 \mathrm{~cm}$ sample)

Figure 2 illustrates the Vibrio spp., faecal coliform and total bacterial colonies for the aquaculture water samples tested over a $24 \mathrm{~h}$ period. Compared to the $\mathrm{Co}$, the populations of waterborne Vibrio spp., faecal coliform and total bacteria in the PP and MP were significantly $(p<0.05)$ decreased at $30 \mathrm{~min}$. Furthermore, this decrease $(p<0.05)$ was maintained over the $24 \mathrm{~h}$ test period. At $24^{\text {th }} \mathrm{h}$, Vibrio spp. and faecal coliform in PP were decreased by $68.7 \%$ and $66.3 \%$, while they were reduced by $75.0 \%$ and $67.1 \%$ in MP (Figures 2a and 2b). As expected in $60 \mathrm{~cm}$ water layer, total bacterial colonies in PP were higher $(p<0.05)$ than those in MP due to stronger bioflocculating activity for MP. The total bacterial populations in MP and PP were decreased by $66.3 \%$ and $26.5 \%$, respectively, compared to those of Co at $24^{\text {th }} \mathrm{h}$ (Figure $2 \mathrm{c}$ ).

\section{3 $\gamma$-PGA concentration and total bacterial population in the bottom (119 cm sample)}

The $\gamma$-PGA concentration and total bacterial population of the bottom water $(119 \mathrm{~cm})$ were measured and shown in Figures 3a and $3 \mathrm{~b}$. Compared to $\gamma$-PGA concentrations examined at $30 \mathrm{~min}$, they showed a $57.0 \%$ and $31.7 \%$ reduction for PP and MP at $24^{\text {th }} \mathrm{h}$. Additionally, MP maintained a significantly higher $(p<0.05) \quad \gamma$-PGA concentration than PP. Unlike the $60 \mathrm{~cm}$ sample, the total bacterial colonies of the $119 \mathrm{~cm}$ sample in both PP and MP, were significantly higher $(p<0.05)$ than the Co. Furthermore, inconsistent with the $60 \mathrm{~cm}$ sample data, the number of isolated bacterial colonies from MP was significantly higher $(p<0.05)$ than that from PP. The total bacterial colonies at $24^{\text {th }} \mathrm{h}$ in MP were 10.3 and 2.5 times higher than those of the Co and PP, respectively. 


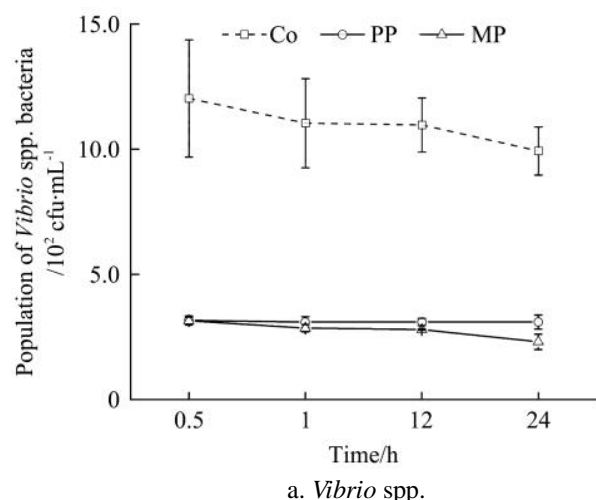

a. Vibrio spp.

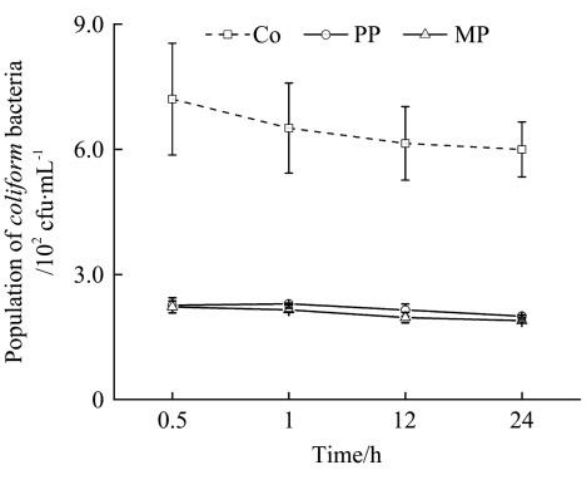

b. Faecal coliform

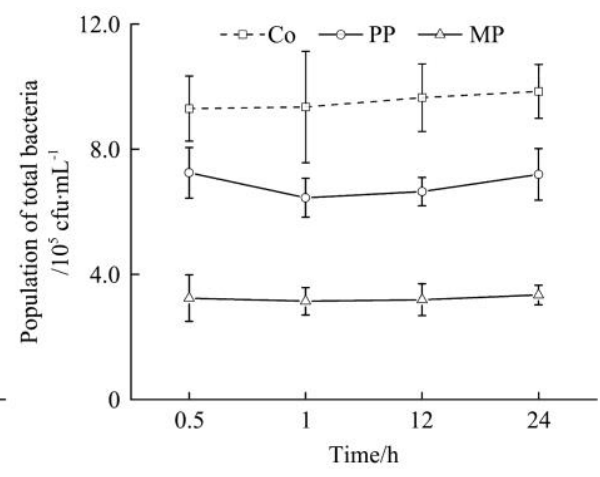

c. Total bacteria

Note: The data are presented as the means \pm SD.

Figure 2 Population of (a) Vibrio spp., (b) faecal coliform and (c) total bacteria from aquaculture wastewater $(60 \mathrm{~cm}$ sample)

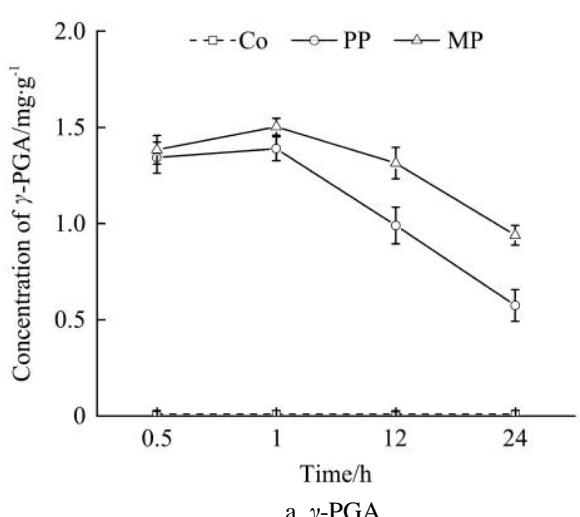

a. $\gamma$-PGA

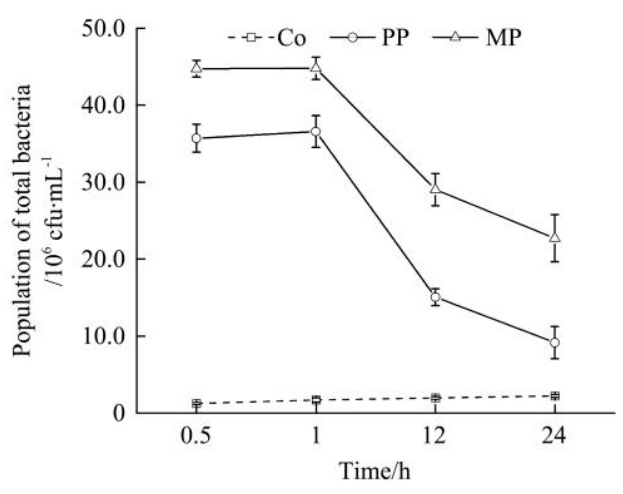

b. Total bacterial

Note: The data are presented as the means $\pm \mathrm{SD}$

Figure 3 Concentration of (a) $\gamma$-PGA and (b) total bacterial population of the bottom water $(119 \mathrm{~cm}$ sample)

\subsection{In situ aquaculture pond water purification}

As shown in Table 3, the spraying of MP into the shrimp pond could significantly lower the concentrations of chemical pollutants compared with the Control and EM treatments $(p<0.05)$ on the $7^{\text {th }}$ day. It indicated that turbidity, $\mathrm{COD}, \mathrm{NH}_{4}{ }^{+}-\mathrm{N}, \mathrm{NO}_{3}{ }^{-} \mathrm{N}$ and $\mathrm{NO}_{2}{ }^{-} \mathrm{N}$ in MP treatment were reduced by $74.1 \%, 65.2 \%, 60.1 \%$, $73.7 \%$ and $78.8 \%$, respectively, compared to Control treatment.

Table 3 In situ aquaculture pond water purification $($ Mean \pm SD)

\begin{tabular}{cccccc}
\hline \multirow{2}{*}{ Treatment } & \multicolumn{2}{c}{ NTU } & & \multicolumn{4}{c}{ Water qualities on the $7^{\text {th }}$ day/mg. $\mathrm{L}^{-1}$} \\
\cline { 2 - 6 } \cline { 5 - 6 } & Turbidity & $\mathrm{COD}$ & $\mathrm{NH}_{4}{ }^{+}-\mathrm{N}$ & $\mathrm{NO}_{3}{ }^{-}-\mathrm{N}$ & $\mathrm{NO}_{2}{ }^{-}-\mathrm{N}$ \\
\hline Control & $56.00 \pm 2.15^{\mathrm{a}}$ & $53.21 \pm 1.57^{\mathrm{a}}$ & $20.18 \pm 1.28^{\mathrm{a}}$ & $13.71 \pm 1.10^{\mathrm{a}}$ & $0.52 \pm 0.03^{\mathrm{a}}$ \\
EM & $43.57 \pm 2.30^{\mathrm{a}}$ & $42.12 \pm 3.15^{\mathrm{a}}$ & $18.23 \pm 2.04^{\mathrm{a}}$ & $11.26 \pm 0.87^{\mathrm{a}}$ & $0.41 \pm 0.01^{\mathrm{a}}$ \\
MP & $14.56 \pm 1.22^{\mathrm{b}}$ & $18.54 \pm 1.11^{\mathrm{b}}$ & $12.12 \pm 0.84^{\mathrm{b}}$ & $3.64 \pm 0.41^{\mathrm{b}}$ & $0.11 \pm 0.02^{\mathrm{b}}$ \\
\hline
\end{tabular}

Note: The values followed by the different lowercase letters in a column are significantly different at the 0.05 level $(p<0.05)$.

\section{Discussion}

Microbial reagents have been shown to be effective in removing COD and inorganic nitrogenous waste originated from the uneaten feed and excretion in aquaculture ${ }^{[4,24]}$. For example, EM used in the aquaculture water purification could transform $\mathrm{NH}_{4}{ }^{+}-\mathrm{N}$ or $\mathrm{NO}_{3}{ }^{-}-\mathrm{N}$ to $\mathrm{N}_{2}$ by nitrification and denitrification ${ }^{[5,6]}$. However, this natural purification process in high-intensity aquaculture is not completed prior to pollutants inflicting damage to aquatic organisms ${ }^{[14,25]}$. The results for MP as bioflocculant presented in this study over a $24 \mathrm{~h}$ experimental period are in line with previously reported data for chemical flocculants, such as polyacrylamide, aluminium and iron compounds ${ }^{[13]}$. The MP showed no bio-toxicity ${ }^{[26,27]}$ and the removal rate of pollutants increased as the application amount of MP increased ${ }^{[5]}$. The removal of pollutants was increased as the extracellular peptide content of the IAE635 increased in PP treatment ${ }^{[28]}$. For MP treatment, it could be the increase in the concentration of starch in the IAE635 ${ }^{[28,29]}$. In aerobic conditions, the nitrosation and nitrification effects of the Bacillus in the water were enhanced to result in a higher removal rate of nitrogenous waste ${ }^{[29]}$. In the previous study, the application of $2 \mathrm{~mL} / \mathrm{L}$ PP/MP was recommended for aquaculture wastewater purification ${ }^{[5]}$. At the same application concentration, MP had a more satisfactory removal rate of pollutants than $\mathrm{PP}$ did.

Our results in this study indicated that the addition of $2 \mathrm{~mL} / \mathrm{L}$ $\mathrm{PP}$ or MP to the aquaculture wastewater could significantly reduce the concentrations of turbidity, $\mathrm{COD}, \mathrm{NH}_{4}{ }^{+}-\mathrm{N}$ and $\mathrm{NO}_{3}{ }^{-}-\mathrm{N}$. The evident reductions for $\mathrm{PP}$ treatment suspected that this purification effect was mainly due to the flocculation of -PGA, not primarily by the microbial processes ${ }^{[11,15]}$. However, the presence of the IAE635 provided a synergistic effect. The in-situ spraying results in this study also indicated that MP could rapidly remove the chemical pollutants compared with EM. It may prove that the purification effects of MP for the chemical pollutants are mainly attributed to the flocculation as the biofloculant, not to the single microbial degradation.

In addition, biotic pollutants such as bacterial pathogens must be considered when selecting aquaculture water purification methods. Vibrio spp. have been reported to be one of the most dangerous groups of pathogens, causing numerous aquatic diseases in aquaculture industry ${ }^{[1,7]}$. Furthermore, higher Vibrio spp. populations in the water produce a potential threat to the aquatic $\operatorname{organisms}{ }^{[1,30,31]}$. Another bacterial pathogens of concern are coliform bacteria because they serve as the indicator of faecal 
contamination in the water ${ }^{[21]}$. This study found that the flocculation induced by $\gamma$-PGA was capable of lowering the amounts of Vibrio spp. and faecal coliform in aquaculture wastewater. It suggests that applications of PP/MP can also effectively decrease the overall use of antibiotics in aquaculture systems. The higher reduction of $\gamma$-PGA concentration collected from the $119 \mathrm{~cm}$ depth in PP-treated sample than in MP-treated sample may be a result of MP having contained the $\gamma$-PGA producing IAE635. Furthermore, our results suggested that IAE635 acted synergistically since MP appeared to purify the aquaculture wastewater better than PP. There existed the sufficient differences for the total bacterial population in different water layers and treatments. The results suggested that the increased population of total bacteria in the $60 \mathrm{~cm}$ depth water via the reaction time was not completely from the release of coagulation in the bottom water. It is assumed that the decrease of total bacteria in the bottom water via the reaction time could have resulted from microbial death or predation among microbes ${ }^{[16,24]}$. A relatively higher level of microbial heterogeneity in the aquaculture system often reduces the vulnerability of aquatic organisms to opportunistic bacteria such as Vibrio spp. ${ }^{[1,31]}$ The increase in the PGA for MP compared to PP was attributed to the proliferation of IAE635 to produce, which presumably improved the aquaculture water quality.

\section{Conclusions}

The results of this study indicated that MP was effective in removing the chemical pollutants and dangerous pathogens from aquaculture water by flocculation and microbial decomposition. Specifically, compared to the Co, the removal efficiencies of turbidity, $\mathrm{COD}, \mathrm{NH}_{4}{ }^{+} \mathrm{N}, \mathrm{NO}_{3}{ }^{-} \mathrm{N}$, Vibrio spp. and coliform bacteria at $24^{\text {th }} \mathrm{h}$ were $87.9 \%, 93.5 \%, 86.5 \%, 78.0 \%, 75.0 \%$ and $67.1 \%$, respectively. Additionally, there was a significant increase in water purity of the aquaculture system as a result of using MP compared to PP or EM. MP decreased the population of Vibrio spp. and coliform bacteria in the aquaculture wastewater better than PP did. The application of MP will benefit the aquaculture industry by providing an effective and sustainable method for the removal of chemical pollutants and pathogens. Therefore, this study provides a novel measure for treating high-intensity aquaculture wastewater and guidance on how to reduce the emission of coastal aquaculture wastewater to the marine environment.

\section{Acknowledgements}

This work was financially supported by the Major Science and Technology Program for Water Pollution Control and Treatment of China (Grant No. 2017ZX07108-001), the Fundamental Research Funds for the Central Universities (Grant No. 2019B18314) and the Jiangsu Scientific Research Program (Grant No. BE2017765). This work was also supported by a grant from the Science and Technology Project for Nanjing Water Conservancy Bureau (2019-208-6) and China Scholarship Council (CSC). The authors would like to acknowledge the University of Melbourne for the research resources.

\section{[References]}

[1] Pang S J, Xiao T, Bao Y. Dynamic changes of total bacteria and Vibrio in an integrated seaweed-abalone culture system. Aquaculture, 2006; 252(2): 289-297.
[2] Crab R, Defoirdt T, Bossier P, Verstraete W. Biofloc technology in aquaculture: Beneficial effects and future challenges. Aquaculture, 2012; 3(5): 351-356.

[3] Li G, Bai X, Huo S, Huang Z. Fast pyrolysis of LERDADEs for renewable biofuels. IET Renewable Power Generation, 2020; 14(6): 959-967.

[4] Boopathy R, Kern C, Corbin A. Use of Bacillus consortium in waste digestion and pathogen control in shrimp aquaculture. International Biodeterioration \& Biodegradation, 2015; 102(1): 159-164.

[5] Shao Y L, Zhong H, Chen L H. Microbiologic technology for purifying coastal aquaculture water. Fresenius Environmental Bulletin, 2018; 27: 3796-3802.

[6] Wang L, Shao X, Xu M, Chen S. Bioremediation of nitrogen- and phosphorus-polluted aquaculture sediment by utilizing combined immobilized effective microorganisms and sediment aeration technology. Inter J Agric \& Biol Eng, 2019; 12(6): 192-201.

[7] Fan L, Chen J, Liu Q, Wu W, Meng S, Song C, et al. Exploration of three heterotrophic nitrifying strains from a tilapia pond for their characteristics of inorganic nitrogen use and application in aquaculture water. Journal of Bioscience \& Bioengineering, 2015; 119(3): 303-309.

[8] Travaini-Lima F, Andreia M S D V M, Sipauba-Tavares L J. Constructed wetland for treating effluent from subtropical aquaculture farm. Water Air \& Soil Pollution, 2015; 226(3): 1-10.

[9] Zhang X, Hu J, Spanjers H, van Lier J B. Performance of inorganic coagulants in treatment of backwash waters from a brackish aquaculture recirculation system and digestibility of salty sludge. Aquacultural Engineering, 2014; 61(3): 9-16

[10] Tomasa D C C M, Rodríguez R A, Voltolina D, Morquecho L. Effectiveness of coagulants-flocculants for removing cells and toxins of Gymnodinium catenatum. Aquaculture, 2016; 21(2): 678-688.

[11] Li G, Lu Z, Zhang J, Li H, Zhou Y, Mohammed I Z A, et al. Life cycle assessment of biofuel production from microalgae cultivated in anaerobic digested wastewater. Inter J Agric \& Biol Eng, 2020; 13(1): 241-246.

[12] Okaiyeto K, Nwodo U U, Mabinya L V, Okoh A I. Evaluation of the flocculation potential and characterization of bioflocculant produced by Micrococcus sp. Leo. Applied Biochemistry \& Microbiology, 2014; 50(6): 601-608.

[13] Salehizadeh H, Yan N. Recent advances in extracellular biopolymer flocculants. Biotechnology Advances, 2014; 32(8): 1506-1522.

[14] Ugbenyen A M, Cosa S, Mabinya L V, Okoh A I. Bioflocculant production by Bacillus sp. Gilbert isolated from a marine environment in South Africa. Applied Biochemistry \& Microbiology, 2014; 50(1): 49-54.

[15] Gong W X, Wang S G, Sun X F, Liu X W, Yue Q Y, Gao B Y. Bioflocculant production by culture of Serratia ficaria and its application in wastewater treatment. Bioresource Technology, 2008; 99(11): 4668-4674.

[16] Li G, Zhang J, Li H, Hu R, Yao X, Liu Y, et al. Towards high-quality biodiesel production from microalgae using original and anaerobicallydigested livestock wastewater. Chemosphere, 2020; 4: 128578.

[17] Kim D G, La H J, Ahn C Y, Park Y H, Oh H M. Harvest of Scenedesmus sp. with bioflocculant and reuse of culture medium for subsequent high-density cultures. Bioresource Technology, 2011; 102(3): 3163-3168.

[18] Zhao H, Liu H, Zhou J. Characterization of a bioflocculant MBF-5 by Klebsiella pneumoniae and its application in Acanthamoeba cysts removal. Bioresource Technology, 2013; 137(3): 226-232.

[19] Chen L H, Huang X Q, Zhang F G, Zhao D K, Yang X M, Shen Q R. Application of Trichoderma harzianum SQR-T037 bio-organic fertiliser significantly controls Fusarium wilt and affects the microbial communities of continuously cropped soil of cucumber. Journal of the Science of Food and Agriculture, 2012; 92(12): 2465-2470

[20] Ghosh M, Ganguli A, Pathak S. Application of a novel biopolymer for removal of Salmonella from poultry wastewater. Environmental Technology, 2009; 30(4): 337-344.

[21] Lee G C, Jheong W H, Kim M J, Choi D H, Baik K H. A 5-year survey (2007-2011) of enteric viruses in Korean aquatic environments and the use of coliforms as viral indicators. Microbiology and Immunology, 2013; 57(1): 46-53.

[22] Kriem M R, Banni B, Bouchtaoui H E, Hamama A, Quilici M L. Prevalence of Vibrio spp. in raw shrimps (Parapenaeus longirostris) and performance of a chromogenic medium for the isolation of Vibrio strains. Letters in Applied Microbiology, 2015; 61(3): 231-240.

[23] Ruxton T, Graeme D, Beauchamp Y, Guy Y K. Time for some a prior thinking about post hoc testing. Behavioral Ecology, 2008; 3(1): 161-172.

[24] Lertsutthiwong P, Sutti S, Powtongsook S. Optimization of chitosan 
flocculation for phytoplankton removal in shrimp culture ponds. Aquacultural Engineering, 2009; 41(3): 188-193.

[25] De-Bashan L E, Trejo A, Huss V A R, Hernandez J P, Bashan Y. Chlorella sorokiniana UTEX 2805, a heat and intense, sunlight-tolerant microalga with potential for removing ammonium from wastewater. Bioresource Technology, 2008; 99(11): 4980-4989.

[26] Bajaj I, Singhal R. Poly (glutamic acid)- an emerging biopolymer of commercial interest. Bioresource Technology, 2011; 102(10): 5551-5561.

[27] Wang N, Yang G, Che Y, Liu C. Heterogenous expression of poly- $\gamma$-glutamic acid synthetase complex gene of Bacillus licheniformis WBL-3. Applied Biochemistry \& Microbiology, 2011; 5(2): 54-61.

[28] Wu Q, Ni M, Dou K, Tang J, Ren J, Yu C, et al. Co-culture of Bacillus amyloliquefaciens ACCC11060 and Trichoderma asperellum GDFS1009 enhanced pathogen-inhibition and amino acid yield. Microbial Cell Factories, 2018; 17(1): 347-356.

[29] Li G, Ji F, Bai X, Zhou Y, Dong R, Huang Z. Comparative study on thermal cracking characteristics and bio-oil production from different microalgae using Py-GC/MS. Inter J Agric \& Biol Eng, 2019; 12(1): 208-213.

[30] Thanigaivel S, Vijayakumar S, Mukherjee A, Chandrasekaran N, Thomas J. Antioxidant and antibacterial activity of Chaetomorpha antennina against shrimp pathogen Vibrio parahaemolyticus. Aquaculture, 2014; 433: $467-475$.

[31] Li G, Bai X, Li H, Lu Z, Zhou Y, Wang Y, et al. Nutrients removal and biomass production from anaerobic digested effluent by microalgae: A review. Inter J Agric \& Biol Eng, 2019; 12(5): 8-13. 